Australian Journal of

Educational Technology

\title{
Can computer technology affect teenage attitudes towards AIDS?
}

\author{
R. C. MacGregor \\ Department of Business Systems \\ University of Wollongong \\ B. K. Gibbons \\ Illawarra Electricity \\ Wollongong, Australia
}

Over the past five years the issue of AIDS has been a major concern for health education professionals and an examination of the literature suggests there have been a variety of initiatives undertaken. Gruen et al (1991) have demonstrated significant increases in student knowledge through the involvement of medical and professional personnel in the establishment of a school based AIDS teaching unit. Walker et al (1991) have utilised AIDS data in statistical computing courses as a means of more up to date data to students, while Lipson and Brown (1991) have reported some modest 'success' utilising video tapes.

While most studies report an increase in knowledge and awareness of AIDS by students, results are far from conclusive when questions of attitudes arc examined. For example, Strauss et al (1992), in a study of 429 college students developed an interdisciplinary approach towards AIDS which, they suggested, demonstrated some measure of sustained attitudinal change, however a similar approach carried out by Moskal (1991) failed to produce any modification of high risk behaviour amongst adolescents. Studies in Australia (Turtle et al 1989, Gray and Patterson 1991, Kippax and Crawford 1991) likewise found that while knowledge increases, attitudes, both towards personal sexual activity and tolerance towards those with AIDS, did not significantly alter. This is supported by a number of studies carried out by various governments and researchers throughout the world: 
Russia

Germany

Egypt

Yugoslavia

New Zealand

Zimbabwe
Bogdanova et al (1991)

Schutzwohl and Schulz-Kinderman (1991)

Farghaly and Kamal (1991)

Ajdukovic and Ajdukovic (1991)

Chetwynd (1991)

Munodawafa (1991)

It would seem, then, that for an education program concerning AIDS to be of relevance, it must effect a change both to the knowledge of the recipient as well as the attitudes of the recipient. It is therefore appropriate to consider the concept of attitude, with respect to AIDS and to examine factors which appear to affect attitudes in adolescents.

\section{Attitudes towards AIDS}

Based on a study of undergraduates, Clift and Sears (1989) consider that attitudes towards AIDS can be subdivided into four categories. These are:

- whether AIDS should be thought about and discussed by adolescents and whether education and/or the media should play a role in such discussions.

- whether current personal sexual habits place an adolescent in a high risk situation and thus whether these sexual habits need to be modified.

- whether precautionary measures should be used where drugs are involved or where more than one partner is involved.

- whether employers, schools, hospitals, etc, should discriminate against homosexuals or people with HIV infection.

While only a pilot study, the findings suggested that with the exception of the first category there was a divergence of viewpoints, coupled with substantial uncertainty. It is appropriate to briefly examine the last three categories suggested by Clift and Sears and to examine factors which appear to influence the viewpoints in those categories.

\section{Category 2 - Personal sexual habits}

As already noted, many studies have shown that an increase of knowledge does not necessarily bring with it a modification in high risk behaviour. A number of explanations have been given for this. Abrams et al (1991), in accord with Hirschhorn (1987), Vecsey (1991) and Frankenburg (1992) suggested that part of the reason is the belief in the invulnerability of heterosexuals to AIDS. They suggest that many adolescents credit themselves with more responsibility and control over themselves than others have over themselves. Thus while others are irresponsible, the self is safe. Holland et al (1992) consider that this category of attitudes is not a product of knowledge nor is it the combination of knowledge and experience, rather it is aligned to the relative power of the individual in sex negotiation. 
A number of studies have examined the concept of sex negotiation and attitude. Gorman (1989), Chard (1990), Suffet and Lifshitz (1991) found that there is an asymmetry of power between males and females in sex negotiations. Brown et al (1990), Hayes (1991), and Bates and Joubert (1993) suggest that peer group pressure has a direct bearing on empowerment in sex negotiations, while Ingham et al (1992) suggest that ideology and understanding can alter the position of power in sex negotiation.

\section{Category 3 - Use of precautions where more than one partner \\ involved}

While similar to category 2, this set of attitudes examines an individual's view of both their own precautionary tactics as well as the tactics which they believe should be employed by the wider society. A number of studies (Gallois and Callan 1990, Chard 1990, Price 1991) suggest that the gender of the subject, the age of the subject as well as the nationality of the subject tend to effect the viewpoints of the subject. These studies suggest, for example, that there is a gender difference in viewpoints concerning sharing of needles and precautionary tactics (males appear to have more misconceptions of these areas than females, while females tended to be less careful), however this difference narrows from year 8 to year 12 such that ultimately gender does not play a significant role in effecting these attitudes. Some of the misconceptions which appear to affect this set of attitudes is the concept of multiple partners. Pearson (1992) suggests that many adolescents believe that they are with a particular partner at a particular time and that while the partner might ultimately change, this does not constitute multiple partners.

\section{Category 4 - Tolerance towards those with HIV}

Studies by Clift and Sears $(1989,1991)$ suggest not only that adolescents have wide ranging degrees of tolerance towards homosexuals or those who have contracted HIV but that many factors impinge upon those tolerances. Studies suggest that tolerance 'oscillates' depending upon age. Most adolescents appear to be more tolerant at 13 - 14 years of age than they are at $15-16$. This 'peak of intolerance' appears to lessen as the adolescent reaches the ages of $17-18$ years of age. Likewise, females tend to be far more tolerant than their male counterpart.

Not only is tolerance effected by age and gender, but studies suggest that religion, family discussion (or lack of it), education and media have an effect on the tolerance level of adolescence. Recent studies highlighted by Pearson (1992) suggest that information or discussion presented from a perspective of fear can raise levels of intolerance as well as leaving lasting misconceptions concerning HIV infection.

In addressing the question of attitude, Clift and Sears (1991) suggest that lack of attitudinal change can, in many cases, be traced back to the 
methods employed in the teaching of AIDS. In a study of 346 teachers they found that only $34.2 \%$ provided alternatives to high risk sexual activity. Many presented the information from the perspective of fear which has been shown to shift attitudes in the opposite direction to that which was intended (Pearson 1992). Only 11\% of those surveyed indicated that they gave emphasis to skills involved in negotiating safer sex, Similarly, only $11.1 \%$ indicated that they encouraged delaying or even avoiding sexual activity. The study further suggested that less than a third of the teachers provided any emphasis on attitudes towards people with HIV / AIDS. This is supported by Forst et al (1990) who, in a comprehensive review, found that many of the approaches used in AIDS education to be necessarily questionable. They state that few appear to contain mechanisms for self monitoring, few undertake evaluation in any acceptable form resulting in findings which, at best, are open to question.

For an AIDS educational program to be effective, its design must be premised on a need to provide students with sufficient and correct information such that informed decisions concerning lifestyle can be made. Not only should the educational program affect lifestyle, it should be tailored such that an increase in tolerance towards others is achievable. This paper describes the development and content of an instructional software package AIDS/STD, premised on these twin aims, for year 10 students.

This paper begins with a brief overview of the software, together with the criteria upon which the software was developed. The paper then provides details and findings of a pilot study carried out utilising the software. The paper will suggest that, based on the results of the pilot study, user directed software appears to have an effect on the attitudes of middle high school students.

\section{An overview of the AIDS/STD software package}

As stated, one of the principal objectives of any AIDS education course must be to provide information and to correct misinformation concerning AIDS. It should encourage responsible behaviour towards sexuality such that informed decisions concerning lifestyle can be established. In noting the findings of recent AIDS education initiatives which perhaps are best summed up by Forst et al (1990), viz,

Specific programs suffered from design defects that made it impossible to accurately determine their effectiveness. Attitude and behaviour change was not properly addressed by the programs (Forst et al 1990, p147)

In noting the subdivision of attitudes suggested by Clift and Sears (1989), the software package was designed both to provide relevant information and to explore each of the attitudinal categories. Materials included discussion concerning personal habits, both now and in the future, sex 
negotiation, questions of tolerance as well as ready sources of additional information on AIDS. In developing the software a number of design principles were considered mandatory. These included:

- the continual evaluation of design decisions against the overall objectives of the AIDS curriculum and the requirements of the students undertaking such a course of study (Forst et al 1990)

- information should not be presented from the perspective of fear (Pearson 1992) the inclusion and dispelling of myths surrounding HIV infection (Massey 1988, Clift and Sears 1991)

- the presentation of material in the context of everyday life with sufficient emphasis on the process of the disease (Obeidallah et al 1993)

- information should include safe sex negotiation and should attempt to reduce the confusion brought about by peer group pressure (Suffet and Lifshitz 1991, Sates and Joubert 1993)

- discussion should include the effects of alcohol and drugs on safe sex decision making (Seigel and Gibson 1988)

Since the software was designed to be used in the classroom situation, a number of design principles were considered mandatory. These included:

- appearance of all displays should be concise, meaningful, consistent and uncluttered with clear sign posting for the user to keep track of where they are and how they may move to other sections of the software or quit the software (Galitz 1981)

- choice of learning and order of learning should be totally learner controlled (Eraut 1988, Rogers et al 1988)

- movement through the system should be simple and at a rate determined by the learner (Turner and Karasek 1984, MacGregor 1988)

- the learner should decide when he / she is to test acquired knowledge (Soulier 1988)

- no topic should last longer than 20 minutes. Studies by Soulier (1988) suggest that if presentations exceed this time limit, learning decreases significantly.

- information and questions should be at the learner's own level of language (Malone 1984)

- response to the learner should be immediate (Cox and Walker 1990)

- the program should permit the learner to make corrections where possible before the computer actually replies (MacGregor 1988)

The final AIDS/STD software package consists of 6 sections - sexually transmitted diseases, nature of HIV, effects of HIV, prevention and protection strategies, HIV related issues and assignments. With the exception of the assignment section, all sections are further subdivided into specific topics and each section has a quiz. Where applicable, extensive static graphics have been incorporated into the presentation (see figure 1). 
The software designed on a PC based platform. As the software was designed for both classroom use and private study, facilities for capturing student navigation or responses were not included. Not only is the software designed to allow for private study, but through the use of teacher inserted assignment questions (section 6), the student can be directed to specific areas for more in-depth learning.

To use the system the student simply types in the command STD. A menu of the six sections appears on the screen. From this point navigation through the software is entirely learner directed, allowing for repeating or skipping certain sections.

\section{Genital Warts}

What is Genital Warts? Genital Warts are caused by a virus (HPV). The warts can be painless or can itch. In some cases they are hard to see, while in other cases they are quite pronounced.

\section{SYMPTOMS}

In men, symptoms may include red patches or changes on the penis. Symptoms usually appear within eight (8) months of infection but sometimes it can be years later.

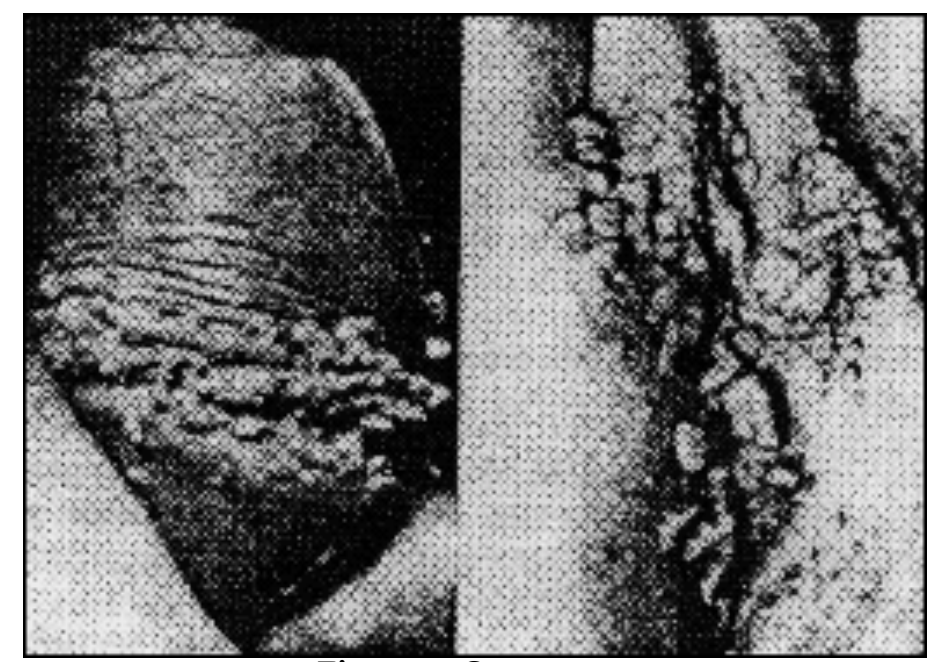

Figure 1: Symptoms

\section{Pilot study}

\section{Sample}

Subjects consisted of ninety six year 10 students who were drawn from four high schools in the Wollongong area. All subjects had been given 10 
weeks ( 1 term) of AIDS education through their normal health education lessons at their school. The ten weeks of AIDS education included the causes of HIV infection, the nature of AIDS, safe sex practices, AIDS and drug abuse. All teachers indicated that some mention had been made of sex negotiation and tolerance but these topics were not explored very deeply. No use had been made of computer technology in the presentations but teachers had made use of video materials, books and some discussion. Teachers indicated that although discussion was carried out, this was often less than effective as many students tried to use the discussions as a forum for humour. While no use of computer technology had been made in the AIDS education sessions, all subjects had used IBM PC microcomputers over the three previous years of their high school study and were familiar with menu style software presentations.

\section{Instrumentation}

A questionnaire, previously applied to year 10 students in an earlier study (Pearson 1992) was used to determine student knowledge and attitudes both before the application of the software and immediately afterwards.

In order to establish content validity, the questionnaire was sent to a panel of 5 health educators and 3 individuals involved in HIV field work. No questions were added or deleted from the questionnaire produced by Pearson, however, on the advice of the panel several response mechanisms were adjusted from a single response to a rating of all possible responses for statistical purposes.

The instrument was pilot tested for test-retest reliability with 30 year 10 students from the same area. An overall reliability measure of correlation between time one and time two was carried out. Results showed knowledge $\mathrm{r}=.87$, attitude $\mathrm{r}=.81$.

The questionnaire sought demographic information (sex, age, religion, major language spoken at home). Table 1 indicates the breakdown of subjects.

Table 1: Breakdown of subjects

\begin{tabular}{llll}
\hline Sex & female & 55 & $57.3 \%$ \\
& male & 41 & $42.7 \%$ \\
\hline Age & 14 & 16 & $16.7 \%$ \\
& 15 & 69 & $71.8 \%$ \\
& 16 & 11 & $11.5 \%$ \\
\hline Major Language & English & 85 & $88.5 \%$ \\
& Other & 11 & $115 \%$ \\
\hline
\end{tabular}


The questionnaire sought information on previous sexual and drug related experience, if any. Table 2 provides a breakdown of those subjects who indicated that they had been sexually active or had used drugs.

The questionnaire had two subscales - knowledge (14 questions) and attitude (11 questions). The knowledge questions examined subject familiarity with issues such as the source of AIDS, methods of becoming infected, who was susceptible and avoidance methods. Questions were designed to illicit a YES/NO/NOT SURE response with subjects simply ticking the relevant box. The 11 attitude questions covered the attitude categories suggested by Clift and Sears (1989).

A five point Likert scale (strongly disagree 1 point, disagree 2 points, undecided 3 points, agree 4 points, strongly agree 5 points) was used on the 11 questions related to attitude.

NOTE: the points applied to the responses were purely for statistical purposes and contained no pre-judgements by the researchers.

Questions focused on: (1) teaching about AIDS in high school, (2) belief about susceptibility to AIDS, (3) discussions with partners about safeguards and screening for AIDS (4) willingness to associate with people who had AIDS and stereotyping blame.

\section{Procedure}

Subjects were taken in groups of 20 and handed two copies of the questionnaire. Each pair of questionnaires was uniquely numbered together with a suffix (1 or -2$)$ to indicate the first or second of the pair. Subjects were asked to fill in the questionnaire (suffixed -1) as truthfully as they could.

Once these were collected, subjects were invited to use the AIDS/STD software on individual microcomputers for a period of 45 minutes. They were told to work their way through the package however they wished and in whatever order they wished. As the software was designed to give the learner control over the order of learning no guidance concerning order of materials was given. 45 minutes was considered adequate to allow students to investigate all facets of the software. Students tended to work through the menu systematically and most students tended to test their knowledge with the quizzes at the end of each section. At the completion of the 45 minute period, the subjects were asked to complete the second questionnaire (suffix -2). 
Table 2

\begin{tabular}{llr}
\hline Sexual Intercourse & Male & 7 \\
& Female & 9 \\
\hline Oral Sex & Male & 11 \\
& Female & 10 \\
\hline Number of partners & 1 & 14 \\
(in last 12 months) & $>1$ & 7 \\
\hline Knew partner's history & Yes & 13 \\
& No & 8 \\
\hline Use Condom & Never & 5 \\
& Seldom & 5 \\
& Sometimes & 3 \\
& Mostly & 3 \\
& Always & 5 \\
\hline Reason for not using & Didn't have any & 3 \\
a condom & Didn't have time & 2 \\
& Don't like them & 3 \\
& Unplanned sex & 6 \\
& Partner wouldn't & 2 \\
\hline Shared needles & & 1 \\
\hline
\end{tabular}

\section{Data Analysis}

All unanswered responses were ignored. In noting the need for awareness in student populations of ethnicity, age differences, sex and high risk groups suggested by Seigel et al (1991), change of response to the questionnaires was analysed across sex, English/Non-English spoken at home and sexual activity / inactivity. A two-tailed t-test $(p<0.05)$ was used since the change of response involved dependent sample groups.

As the pilot study was primarily designed to determine if the software did modify knowledge or attitudes in specific sub-groups of the subjects, no cross-group comparisons were carried out.

\section{Results}

An examination of the 14 knowledge questions showed that there was no significant change in response when comparing the answers of the two questionnaires.

The 11 attitude questions were examined across sex, language spoken in the home and sexual activity. Table 3 indicates the mean and standard deviation of the changes in questionnaire responses for each of the subgroups. 
Table 3

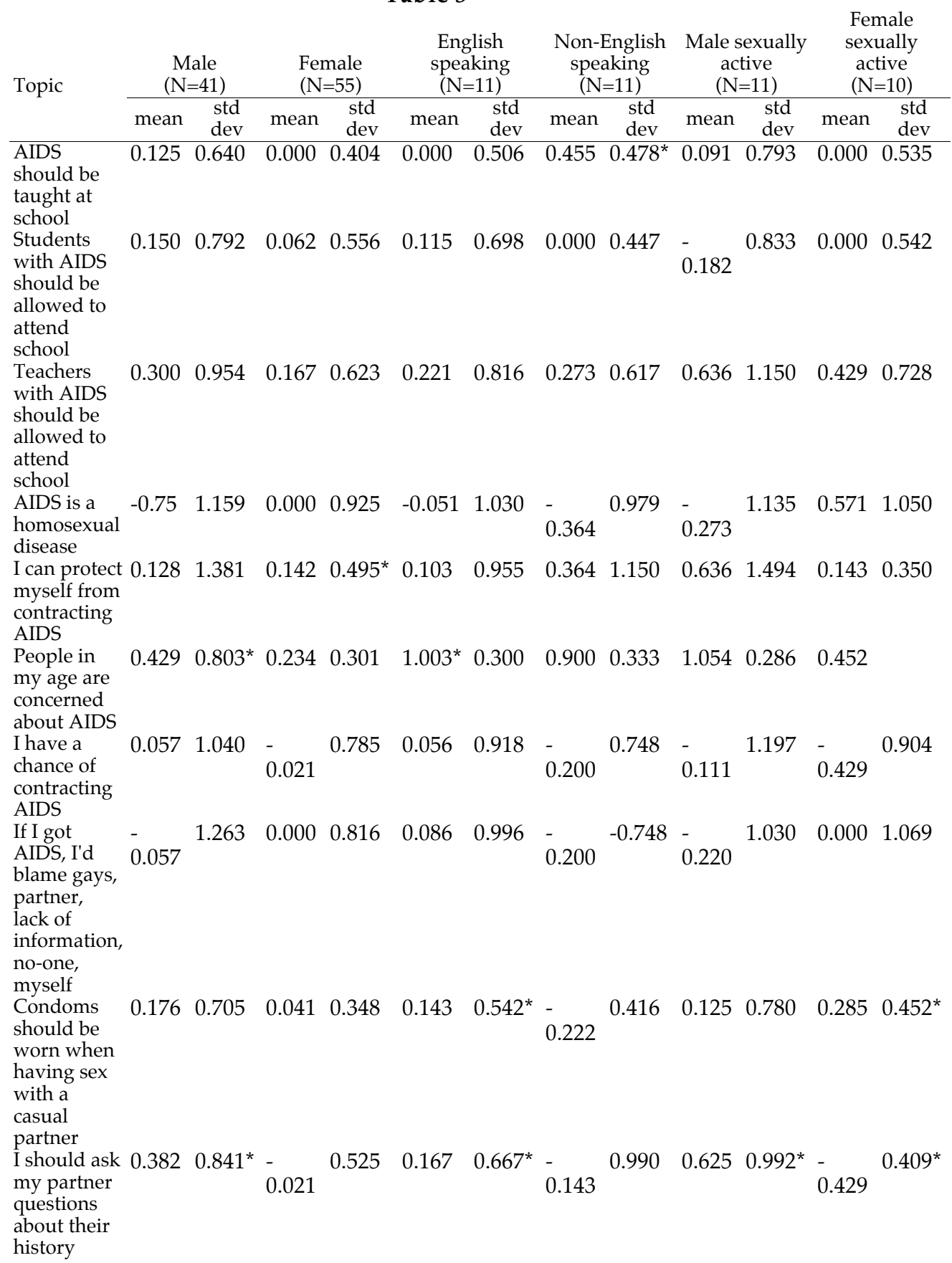




\begin{tabular}{|c|c|c|c|c|c|c|}
\hline $\begin{array}{l}\text { AIDS test- } \\
\text { ing should } \\
\text { be compuls- } \\
\text { ory for } \\
\text { everyone on } \\
\text { a regular } \\
\text { basis }\end{array}$ & 0.3850 .792 * & $0.152 \quad 0.721$ & $0.3380 .934^{*}$ & $0.200 \quad 1.470$ & 0.1110 .567 & $0.000 \quad 0.000$ \\
\hline & $\begin{array}{ll}\text { mean } & \begin{array}{c}\text { std } \\
\text { dev }\end{array} \\
\end{array}$ & $\begin{array}{ll}\text { mean } & \begin{array}{c}\text { std } \\
\text { dev }\end{array} \\
\end{array}$ & $\begin{array}{l}\text { std } \\
\text { dev }\end{array}$ & $\begin{array}{ll}\text { mean } & \begin{array}{c}\text { std } \\
\mathrm{dev}\end{array}\end{array}$ & $\begin{array}{l}\text { std } \\
\text { dev }\end{array}$ & $\begin{array}{l}\text { std } \\
\text { dev }\end{array}$ \\
\hline Topic & $\begin{array}{c}\text { Male } \\
(\mathrm{N}=41)\end{array}$ & $\begin{array}{l}\text { Female } \\
(\mathrm{N}=55)\end{array}$ & $\begin{array}{c}\text { English } \\
\text { speaking } \\
(\mathrm{N}=11)\end{array}$ & $\begin{array}{c}\text { Non-English } \\
\text { speaking } \\
(\mathrm{N}=11)\end{array}$ & $\begin{array}{c}\text { Male } \\
\text { sexually } \\
\text { active } \\
(\mathrm{N}=11)\end{array}$ & $\begin{array}{l}\text { Female } \\
\text { sexually } \\
\text { active } \\
(\mathrm{N}=10)\end{array}$ \\
\hline
\end{tabular}

${ }^{*}$ All significant at or below .05 level

\section{Discussion}

As mentioned previously, Clift and Sears (1989) suggested 4 categories of attitudes. It is appropriate to examine the results of the pilot study in the light of those categories.

\section{Category 1 - AIDS should be thought about by adolescents and discussed at school}

An examination of the results in table 3 suggest that following the intervention of the software males became 'more concerned' with the question of AIDS as did the group of students who indicated that they spoke English as a first language. By comparison, there was no significant change in this attitude by the female population nor by those students who indicated that they spoke English as a second language. Of interest, however, is the change in attitude of the English second language group to the teaching of AIDS at school. While this group has only a small population, there is a significant change in their attitude concerning the teaching of AIDS following the intervention of the software.

\section{Category 2 - Personal sexual habits}

In separate studies, Gorman (1989), Chard (1990) and Suffet and Lifshitz (1991) have suggested that in the area of safe sex negotiation there is an asymmetry of power between males and females. An examination of Table 2 would suggest that the intervention of the software appeared to have differing effects on males and females. Females became more positive as to their own roles in protecting themselves from HIV infection. By comparison males became more concerned with HIV / AIDS and appeared to agree more strongly with the need for both regular testing for AIDS and the need for knowledge about potential sex partners.

Hirschhorn (1987), Vecsey (1991) and Frankenburg (1992) have shown that there is a wide spread belief in the invulnerability of contracting AIDS amongst heterosexuals. The results presented in Table 3 suggest that the intervention of the software has resulted in male adolescents becoming more concerned with AIDS while their female counterparts have 
significantly increased their belief in the need for protection during sexual activity.

\section{Category 3 - Use of precautions where more than one partner involved}

When looking at questions concerned with more than one partner, the intervention of the software had differing effects on males and females who were sexually active. Females who were sexually active showed a significant move away from questioning potential sexual partners, apparently opting instead for the use of condoms as a safeguard in casual sex. By comparison the males did not indicate a significant change towards the use of condoms, but did significantly change their attitude towards the questioning of potential partners in casual sex.

The results also suggest that the intervention of the software had a significant effect on the male population in both the areas of questioning a potential partner and the need for regular AIDS testing. This does not appear to be the case with their female counterparts. Of particular interest is the comparison of English speaking student and non-English speaking students. While the number for non-English students is small, the results tend to suggest that the software has a more pronounced effect on those who speak English as a first language than those who do not. Indeed, in the questions of use of condoms, the need to question potential sex partners, and the need for regular AIDS screening, there was a significant change of attitude by those who indicated that they spoke English as a first language as compared to those who do not.

\section{Category 4 - Tolerance towards those with AIDS}

An examination of the results in table 3 suggest that for the most part tolerance of students did not significantly change. Indeed, the only exception to this was the question concerning teachers with AIDS being allowed to attend school. While neither the male nor the female population showed any significant change, the group who spoke English as a first language did show a significant change of attitude concerning teachers with AIDS.

\section{Conclusion}

A number of studies (Grey \& Patterson 1991, Henry 1991, Kippax \& Crawford 1991) have suggested that while educational endeavours appear to bring about knowledge increases in the area of AIDS education, attitudes do not appear to be significantly altered. While only a pilot study on a small number of subjects, the results seem to suggest that a learner directed approach using computer technology may be a viable alternative.

Unlike many other forms of educational presentation, computer technology allows individuals to move at their own pace, to examine text 
and graphics many times and to test their knowledge and understanding through in-built quizzes. Based on their performance with quizzes students then gain a better idea of those areas which need to be 're-visited' for further examination.

The results suggest that a change of some of the categories of attitudes and beliefs is obtainable through the use of computer software. While only a pilot study the software appears to provide females a more positive belief in their own ability to protect themselves in sexual negotiations and appears to give the males a greater awareness of the consequences of unsafe practices.

We have presented a description of the development and the pilot testing of instructional software for year 10 students which appears to go some way to developing positive attitudes in those students tested. For future software to be better aligned to the needs of the adolescent there is an obvious need for more detailed examination to be made of the effect of sex, ethnicity, age, sexual activity/inactivity on the attitudes and changes of attitudes of students.

\section{References}

Abrams, D., Abraham ,C., Spears, R. \& Marks D. (1990). AIDS Invulnerability: Relationships, Sexual Behaviour and Attitudes among 16 -19 Year Olds. In Aggleton, P., Davies, P. \& Hart, G. (eds), AIDS: Individual, Cultural and Policy Dimensions. Falmer Press, UK.

Ajdukovic ,D. \& Ajdukovic, M. (1991). University students and AIDS: Knowledge, attitudes and behavioural adjustment. Psychological Report, 69(1), 203-210.

Bates, L. W. \& Joubert, C. E. (1993). Source of sex education in relation to self esteem and attitudes towards AIDS precautions among college students. Psychological Report, 72(2), 603-606.

Bogdanova, T. F., Batashev, V. V., Prometnoi, V. I. \& Krughov, V. D. (1991). Assessing the level of informed knowledge of the population on the AIDS problem by anonymous questionnaire. ZH-Mikrobiol Epidemiol Immunobiol, 1, 22-24.

Brown, L. K., Nassau, J. H. \& Barone, V. J. (1990). Differences in AIDS knowledge and attitudes by grade level. Journal of School Health, 60(6), 270-275.

Chard, J. (film producer) (1990). Women, HIV and AIDS. Hummingbird Film Productions, UK.

Chetwynd, J. (1991). Knowledge about HIV / AIDS amongst the New Zealand public. New Zealand Medical Journal, 104(923), 473-475.

Clift, S. \& Sears, D. (1989). Undergraduates Beliefs and Attitudes about AIDS. In Aggleton, P., Hart G., \& Davies, P. (eds), AIDS: Social Representations and Social Practices. Falmer Press, UK. 
Clift, S. \& Sears, D. (1991). Moral Perspectives and Safer Sex Practice: Two Themes in Teaching about HIV and AIDS in Secondary School. In Aggleton, P., Hart, G. \& Davies, P. (eds), AIDS: Responses, Interventions and Cares. Falmer Press, UK.

Cox, K. \& Walker, D. (1990). User Interface Design. Advanced Education Software, Canberra.

Eraut, M. (1988) .What has happened to learning design. In Mathias, H., Rushby, N., \& Budgett, R. (eds.), Aspects of Educational Technology, vol. XXI Designing New Systems and Technologies for Learning, Kogan Page, London.

Farghaly, A. G. \& Kamal, M. M. (1991). Study of the opinion and level of knowledge about AIDS problem among secondary school students and teachers in Alexandria. Journal of the Egyptian Public Health Association, 66(1), 209-225.

Forst, M., Moore, M. \& Jang, M. (1990). Issues in the evaluation of AIDS education programs: The case of California. Evaluation and the Health Professions, 13(2), 147-167.

Frankenburg, R. (1992). Medical anthropology and AIDS - The other who is also the same: the relevance of epidemics in space and time for prevention of HIV infection. International Journal of Health Services, 22(1), 73-88.

Galitz, W. O. (1981). Handbook of screen format design. QED, Information Sciences, Mass.

Gallois, C \& Callan, V. J. (1990). Sexuality in Adolescence. In Heaven, P. C. \& Callan, V. J. (eds), Adolescence: An Australian Perspective. Harcourt Brace Jovanovitch, Sydney.

Gorman, P (1989). Educating Students about HIV / AIDS. Feminist Teacher, 4(2),13-15.

Gray, T. \& Patterson, J. (1991). AIDS education in a tertiary setting: A litmus test for effectiveness. Behavioural Medicine Conference, Sydney.

Gruen, S. M., Hayes, E. \& Fritsch-deBruyn, R. (1991). Setting up a schoolbased sexual education program to help prevent AIDS and other sexually transmitted diseases. Nurse Practitioner, 16(8), 47-51.

Hayes, J. A. (1991). Psychosocial barriers to behaviour change in preventing human immunodeficiency virus (HIV) infection. Counselling Psychologist, 19(4), 585-602.

Henry, K., Willenbring, K. \& Grossley, K. (1988). Human Immunodeficiency virus antibody testing: a description of practices and policies at US infectious disease teaching hospitals and Minnesota hospitals. JAMA, 259, 1819-1822.

Hirschhorn, M. W. (1987). AIDS is not seen as a major threat by many heterosexuals on campus. Chronicle of Higher Education, 33(33), 32-34.

Holland, J., Ramazanoglu, C., Scott S., Sharpe S. \& Thomson R. (1992). Pressure, Resistance, Empowerment: Young women and the negotiation of safer sex. In Aggleton P., Davies P. \& Hart G. (eds), AIDS: Rights, Risks and Reasons. Falmer Press, UK. 
Ingham, R., Woodcock, A. \& Stenner, K. (1992). The Limitations of Rational Decision-Making Models as Applied to Young Peoples Sexual Behaviour. In Aggleton P., Davies P. \& Hart G. (eds), AIDS: Rights, Risks and Reasons. Falmer Press, UK.

Kippax, S. \& Crawford, J. (1991). Heterosexuals and HIV Transmission: Where do we go from here? National AIDS Bulletin, 5(6), 14-20.

Lipson, J. M. \& Brown, L. T. (1991). Do video tapes improve knowledge and attitudes about AIDS. Journal of American College Health, 39(5), 235243.

MacGregor, R. C. (1988). Individual differences and music composition software: Some possible inclusions. International Conference on Music Education, Canberra.

Malone, T. W. (1984). Towards a theory of intrinsically motivating instruction. In Walker, D. F. \& Hess, R. D. (eds .), Instructional Software. Wadsworth, Calif.

Massey, D. (1988). Teaching About HIV and AIDS. London Health Education Authority, London.

Moskal, R. J. (1991). Effect of a Comprehensive AIDS Curriculum on Knowledge and Attitudinal Change in Northern Canadian College Students. Canadian Journal of Counselling, 25(3), 338-348.

Munodawafa, D. (1991). Attitudes of teachers towards implementing AIDS prevention education programs in secondary schools in Zimbabwe. Central African Journal of Medicine, 37(12), 390-393.

Obeidallah, D., Turner, P., Iannotti, R. J., O'Brien R. W., Haynie D. \& Galper D. (1993). Investigating Children's knowledge and understanding of AIDS. Journal of School Health, 63(3), 125-129.

Pearson, P. (1992). High School Student' Knowledge, Attitude E Behaviour Towards HIV/AIDS. Unpublished Masters Thesis, University of Wollongong.

Price, J. (1991). Some Kids Play the Field - Others Play the Waiting Game. Sydney Morning Herald, 18th July, p1.

Rogers, Y., Leiser, R. \& Carr, D. (1988). Evaluating metaphors for use at the user system interface. Eurinfo, Athens.

Schutzwohl, M. \& Schulz-Kinderman, F. (1991). AIDS Prevention: Cognitive Emotional approach to the topic of AIDS and behaviour change. Offentl-Gesundheitswes, 53(4), 167-174.

Seigel K., Lazarus N., Krasnovsky F., Durbin M., \& Chesney M. (1991). Barriers to the Modification of Sexual Behaviour Among heterosexuals at Risk for AIDS. New York State Journal of Medicine, 8, 66-70.

Seigel, K. \& Gibson, W. (1988). Barriers to the Modification of Sexual Behaviour Among Heterosexuals at Risk for AIDS. New York State Journal of Medicine, 8, 66-70.

Soulier, J. S. (1988). The design and development of computer based instruction. Allyn \& Bacon, Boston. 
Strauss, R. P., Corless, I. B., Luckey, J. W., Vanderhorst C. M. \& Dennis B. H. (1992). Cognitive and Attitudinal Impacts on a University AIDS Course: Interdisciplinary Education as a Public Health Intervention. American Journal of Public Health, 82(4), 569-572.

Suffet, F. \& Lifshitz, M. (1991). Women Addict and the threat of AIDS. Qualitative Health Research, 1(1), 51-79.

Turner, J. A. \& Karasek, R. A. jnr (1984). Software ergonomics: Effects of computer application design parameters on operator task performance and health. Ergonomics, 27(6), 663-690.

Turtle, A. M., Ford, B., Habgood, R., Grant, M., Bekiari,s J., Constantinou, C., Macek, M. and Polyzoidus, H. (1989). AIDS Related Beliefs and Behaviours of Australian University Students. The Medical Journal of Australia, 150, 371-376.

Vecsey, G. (1991). Why we must heed the message of Magic's fate! Sydney Morning Herald, November 11, p86.

Walker, P. W., Stewart, C. K. and Avdevich, C. K. (1991). Computer Skills Course Integrates AIDS Education. Radiological Technology, 63(2), 100104.

Please cite as: MacGregor, R. C. and Gibbons, B. K. (1994). Can computer technology affect teenage attitudes towards AIDS? Australian Journal of Educational Technology, 10(2), 103-118.

http: / / www.ascilite.org.au / ajet/ajet10 / macgregor.html 